\title{
The impact of bleeding patterns and hormonal contraceptives on migraine headache: a retrospective cross-sectional study
}

Melinda Vanya M.D. ${ }^{1}$, Ivan Devosa ${ }^{3}$, Marta Szucs M.D. ${ }^{1}$, Fanni Bokros ${ }^{2}$, Delia Szok M.D. Ph.D. ${ }^{2}$, Gyorgy Bartfai M.D. Ph.D. D. Sc. ${ }^{1}$

17th European Congress of Endocrinology, 16-20 May 2015, Dublin, Ireland

${ }^{1}$ Department of Obstetrics and Gynaecology, Faculty of Medicine, Albert Szent-Gyorgyi Clinical Centre, University of Szeged, Szeged, Hungary ${ }^{2}$ Department of Neurology, Faculty of Medicine, Albert Szent-Gyorgyi Clinical Centre, University of Szeged, Szeged, Hungary ${ }^{3}$ Institute of Behavioural Medicine, Faculty of Medicine, Albert Szent-Gyorgyi Clinical Centre, University of Szeged, Szeged, Hungary

\section{Introduction}

Migraine is one of the most common primary headache diseases with typical clinical features [1]. The two major subtypes of migraine are migraine without aura (M0) and migraine with aura (MA). The 1-year prevalence of migraine in adult is between $15 \%$ and $18 \%[2]$.

Menstrual migraine (MM) without aura affects approximately $20 \%$ of female migraineurs in the general population. [3]. The etiology and exact pathomechanism of MM is still unclear. Menses is a well-known trigger factor for MM. Clinical studies revealed an increased incidence of migraine attacks in conditions with falling levels of plasma oestrogen in the menstrual cycle and the use of combined oral contraceptives (COC) [4]. The purpose of the present study were to describe the contraceptive practice and menstrual pattern of women with migraine and to analyse the effect of $\mathrm{COC}$ use and bleeding pattern on the influencing of migraine course

\section{Patients and methods}

The questionnaire-based study have been performed in the Outpatient Unit of Department of Neurology, Szeged, Hungary. We invited women with M0 and MA to participate in the questionnaire-based study. We collected data in two time periods: between 2006-2009 and 2013-2014 and we received the answers via 3 ways: clinical interviews, online and postal way.

All participants ( $\mathrm{n}=186)$ completed a questionnaire containing 25 items compiled by our research team based on our clinical practice and recent international literature research. The questions referred to socio-demographic characteristics, the menstruation cycle pattern (mean age at the first menses, duration of menses, characteristic of menstrual cramps and large amount of bleeding), the contraception habits (use of reliable and less reliable contraceptive methods) and migraine characteristic (including number of headache days, intensity of headpain, use of acute and prophylactic anti-migraine drugs)

Statistical analysis: The associations between COC use, bleeding patterns and clinical characteristics of migraine were compared by the Pearson correlation tests.

The validity process of the questionnaire was performed and internal reliability was also calculated.

The study and questionnaire were approved by the National Ethics Committee of Hungary. The study was performed in a full accordance with the Declaration of Helsinki (1961), and all participants gave their written informed consent (Approval No: 227602/2013/EKU(289/2013)

\section{Results}

Our study group was consisted of 108 women with M0 (58\%) and 78 women with MA $(42 \%)$. The average age of the patients at the diagnosis of migraine was $18.8 \pm 7.0$ years. The mean body weight and the mean body height were $65.7 \pm 16.0 \mathrm{~kg}$ and $165.6 \pm 9.9 \mathrm{~cm}$. The mean age at menarche was $12.3 \pm 2.1$ years.

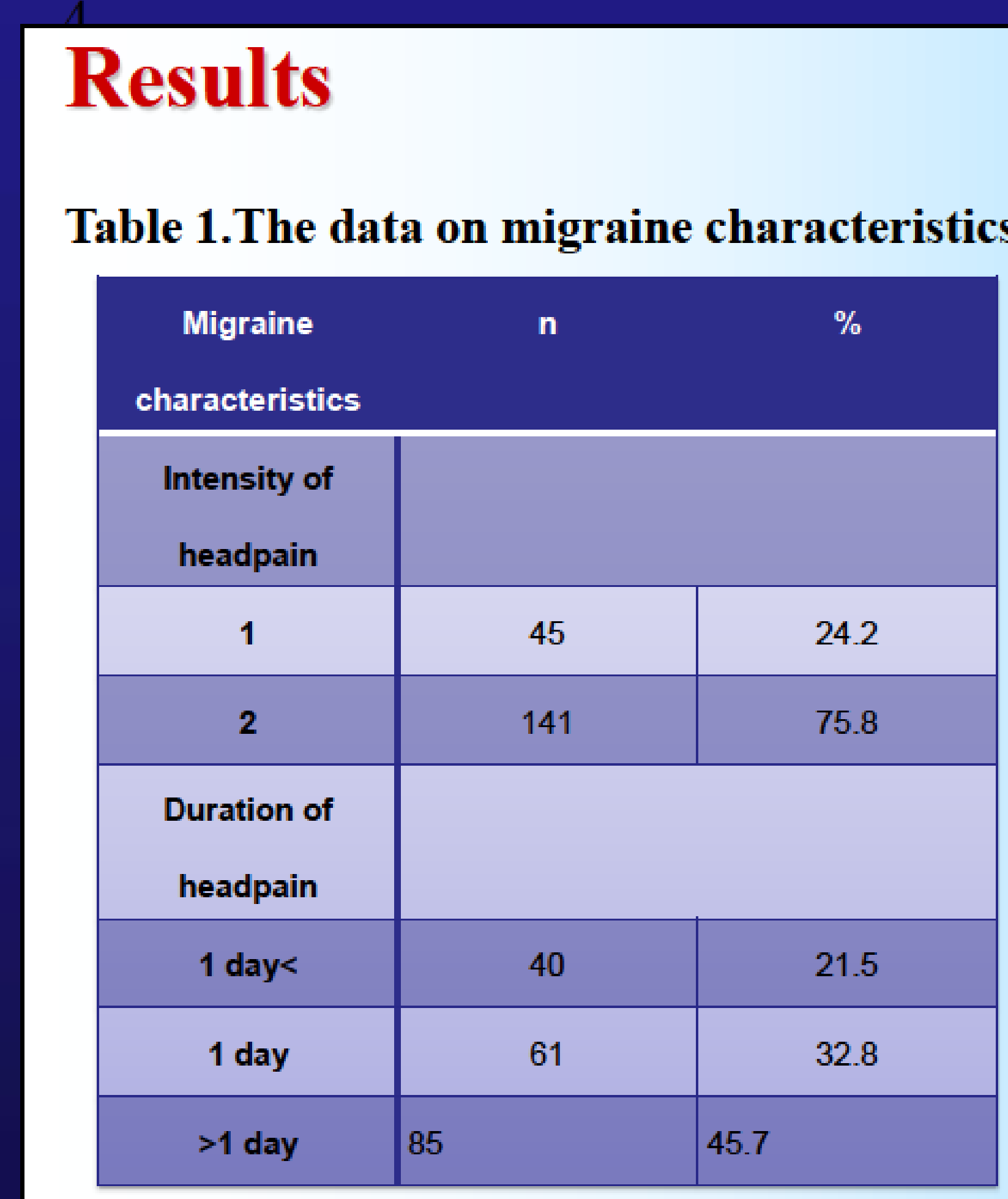

Table 2. Socio-demographic data on female patients with migraine

\begin{tabular}{|c|c|c|}
\hline Age groups & $n$ & $\%$ \\
\hline $18-20$ years & 9 & 4.8 \\
\hline $20-25$ years & 31 & 16.7 \\
\hline $25-30$ years & 30 & 16.1 \\
\hline $30-35$ years & 52 & 28.0 \\
\hline $35-40$ years & 40 & 21.5 \\
\hline$>40$ years & 24 & 12.9 \\
\hline $\begin{array}{l}\text { First menstrual } \\
\text { period (years) }\end{array}$ & \multicolumn{2}{|c|}{$12.3 \pm 2.1$} \\
\hline \multicolumn{3}{|l|}{$\begin{array}{l}\text { Length of menstrual } \\
\text { bleeding }\end{array}$} \\
\hline$>3$ day & 5 & 2.7 \\
\hline 3-5 days & 115 & 61.8 \\
\hline $5-8$ days & 59 & 31.7 \\
\hline$>8$ days & 6 & 3.2 \\
\hline \multicolumn{3}{|l|}{$\begin{array}{l}\text { Large amount of } \\
\text { bleeding (>80 ml) }\end{array}$} \\
\hline No & 159 & 85.5 \\
\hline Yes & 27 & 14.5 \\
\hline \multicolumn{3}{|l|}{ Menstrual cramps } \\
\hline No & 94 & 50.5 \\
\hline Yes & 92 & 49.5 \\
\hline \multicolumn{3}{|l|}{$\begin{array}{l}\text { Changes in body } \\
\text { weight }(+5 \mathrm{~kg})\end{array}$} \\
\hline No & 92 & 49.5 \\
\hline Yes & 94 & 50.5 \\
\hline \multicolumn{3}{|l|}{$\begin{array}{c}\text { Sexual activity } \\
\text { (3/week) }\end{array}$} \\
\hline No & 31 & 16.7 \\
\hline Yes & 155 & 83.3 \\
\hline
\end{tabular}

Table 3. The connection between bleeding pattern and migraine headache

\begin{tabular}{|l|c|c|c|}
\hline \multicolumn{1}{|c|}{$\begin{array}{c}\text { Pearson } \\
\text { Correlation }\end{array}$} & $\begin{array}{c}\text { Use of condom } \\
\text { (years) }\end{array}$ & $\begin{array}{c}\text { Use of IUD } \\
\text { (veans) }\end{array}$ & $\begin{array}{c}\text { Use of COC } \\
\text { (veans) }\end{array}$ \\
\hline Duration of & & & \\
pain & 0.018 & 0.08 & 0.285 \\
Pearson & 0.808 & 0.281 & $0.001^{*}$ \\
Sig. (2-tailed) & 185 & 186 & 127 \\
N & & & \\
\hline Intensity of & & & \\
pain & 0.028 & 0.019 & 0.019 \\
Pearson & 0.706 & 0.306 & $0.021^{*}$ \\
Sig. (2-tailed) & 185 & 186 & 127 \\
N & & & \\
\hline
\end{tabular}

Table 4. The connection between $\mathrm{COC}$ and migraine

\begin{tabular}{|l|c|c|c|}
\hline \multicolumn{1}{|c|}{$\begin{array}{c}\text { Pearson } \\
\text { Correlation }\end{array}$} & $\begin{array}{c}\text { Use of condom } \\
\text { (vears) }\end{array}$ & $\begin{array}{c}\text { Use of IUD } \\
\text { (years) }\end{array}$ & $\begin{array}{c}\text { Use of COC } \\
\text { (vears) }\end{array}$ \\
\hline Duration of & & & \\
pain & 0.018 & 0.08 & 0.285 \\
Pearson & 0.808 & 0.281 & $0.001^{*}$ \\
Sig. (2-tailed) & 185 & 186 & 127 \\
N & & & \\
\hline Intensity of & & & \\
pain & 0.028 & 0.019 & 0.019 \\
Pearson & 0.706 & 0.306 & $0.021^{*}$ \\
Sig. (2-tailed) & 185 & 186 & 127 \\
N & & & \\
\hline
\end{tabular}

The Pearson correlation test revealed a relationship between duration of menstrual cycle and the intensity of headpain $(\mathrm{p}=0.012)$. The duration of $\mathrm{COC}$ use was correlated with the intensity and duration of headpain $(\mathrm{p}=0.001$ and $\mathrm{p}=0.021$ )

\section{Conclusions}

Based upon our research sample we could conclude that there were strong relationship between duration of menstrual cycle and the intensity of headache pain $(p=0.012)$ and the longer COC use and the intensity and duration of headpain in MO group $(\mathrm{p}=0.001$, $\mathrm{p}=0.021$ ). The study of Merki-Feld and his coworkers [5-6] revealed that progesterone only pill (POP) reduced the number of headache days in M0 patients $(n=23)$. Morotti and his coworkers [11] found similar results on $53 \mathrm{M} 0$ patients. Their data confirmed that POP was beneficial for the migraine patterns and improved quality of life of M0 patient. During the follow-up period, the use of POP decreased the use of analgetic drugs compared to use of COC therapy. The majority of our M0 patients $(54.3 \%)$ were used COC, there were no cases of POP users among our patients. Calhoun and his colleagues [12] presented that the use of vaginal ring was associated with a reduced frequency of aura. Our data did not

\section{References}

Headache Classification Committee of the International Headache Society. The International Classification of Headache Disorder

(ICHD) 3rd edition (beta version). Cephalalgia 2013;33:628-808.

Bank J, Marton S. Migraine epidemiology. Headache 2000; 40(2):164-169.

Sacco S, Ricci S, Degan D, Carolei A.
Headache Pain 2012:13(3):177-189.

Headache Pain 2012;13(3):177-189. Vetvik KG, MacGregor EA, Lundqvist C, Russell MB. A clin
menstrual migraine without aura. Cephalalgia 2014 Aug 20.

(1)

Terki-Feld GS, Imthurn B, Langner R, Sándor PS, Gantenbein AR. Headache frequency and intensity in female migraineurs using desogestrel-only contraception: a retrospective pilot diary study. Cephalalgia 2013 Apr;33(5):340-6.

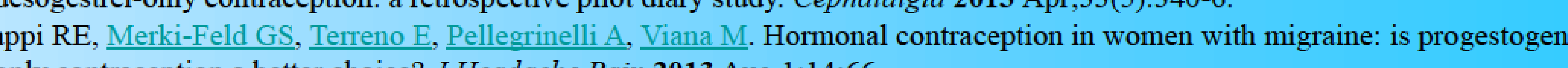
only contraception a better choice? $J$ Headache Pain 2013 Aug 1;14:66.

in wom, Remorgida $V$ Venturini PL, Ferrero $S$. Progestin-only contraception compared with extended combined oral contraceptive in women with migraine without aura: a retrospective pilot study. Eur J Obstet Gynecol Reprod Biol. 2014 Dec;183:178-82. Headache 